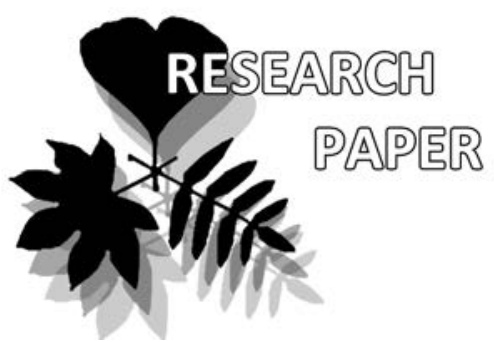

\title{
Milium effusum (Poaceae: Poeae: Miliinae): species of systematic and cytological interest with notes on polymorphic nature and cytogeography
}

\author{
Jaswant Singh ${ }^{1}$, Vijay Kumar Singhal ${ }^{1} \&$ Nina S. Probatova ${ }^{2 *}$
}

Jaswant Singh ${ }^{1}$

e-mail: jaswant_rs@pbi.ac.in

Vijay Kumar Singhal ${ }^{1}$

e-mail: vksinghal53@gmail.com

Nina S. Probatova ${ }^{2 *}$

e-mail:probatova@biosoil.ru

${ }^{1}$ Department of Botany, Punjabi University Patiala, India

${ }^{2}$ Federal Scientific Center of the East Asia Terrestrial Biodiversity FEB RAS,

Vladivostok, Russia

* corresponding author

Manuscript received: 07.09.2021

Review completed: 12.11.2021

Accepted for publication: 12.11.2021

Published online: 15.11.2021

\begin{abstract}
A B S T R A C T
Present communication records polymorphic and polyploid nature of the forest grass species $M$. effusum having wide distribution over different continents and countries. Globally the $4 \mathrm{x}$ plants are widely distributed. The West Himalayan plants, collected at $3000 \mathrm{~m}$ alt. and more, are also sporting chromosome number of $2 \mathrm{n}=28$ based on basic number of $\mathrm{x}=7$. Further meiotic course analysis of Western Himalayan plants follows diploid like behaviour possibly directed by diploidization. This communication also calls the attention to cytogeography of intraspecific cytotypes of $M$. effusum, where diploid plants $(2 \mathrm{n}=14)$ have also been reported, but only 2 times - from the Kola Peninsula, Russia and from the Switzerland mountains. Perhaps these are relict populations, which deserve to be proved, studied and protected.
\end{abstract}

Keywords: grass cytology, cytogeography, male meiosis, polyploidy, dysploidy, conservation

\section{P E 3 Ю M E}

Сингх Аж., Синхам В.К., Пробатова Н.С. Milium effusum (Роасеае: Poeae: Miliinae): виА, преАставляющий систематический и цитологический интерес, с акцентом на полиморфную природу и цитогеографию. Статья посвящена изучению мейоза и полиморфизму у широко распространенного Аесного злака Milium effusum на материале, собранном в Западных Гималаях (Индия), на высотах 3000 м и выше. Кроме цитоморфомогии вила, принадлежащего к небольшому уникальному роду Milium с разнообразными базовыми числами хромосом (х), обсужАается цитогеография M. effusum (соматические числа хромосом); последние были исследованы многими авторами, на разных континентах и в разных странах: $2 \mathrm{n}=28$ (х $=7)$. В ходе работы из материнских клеток пыльцы были получены мейотические препараты $M$. effusum. На основании особенностей мейоза слелан вывод о вероятном гибридном происхожАении виАа, и возможных процесcax Аиплоилизации. Авторы предлагают обратить внимание на 2 местонахождения $M$. effusum с Аиплоидным числом хромосом $2 \mathrm{n}=14$ : в России (Кольский п-ов) и в горах Швейцарии, которые, вероятно, явАяются реАиктовыми и заслуживают охраны. Особ̆енности $M$. effusum, установленные разными методами, свидетельствуют о его полиморфизме.

КАючевые слова: цитология злаков, цитогеография, мужской мейоз, полиплоиАия, Аисплоилия, сохранение
Milium is a genus of annual and perennial species, characteristically inflorescence a panicle composed of solitary and 1-flowered alike spikelets. The recent phylogenetic classification system of grass family, corroborated by molecular and morphological studies placed Milium under subtribe Millinae Dumort., supersubtribe Poodinae L.J. Gillespie \& Soreng, tribe Poeae R. Br., supertribe Poodae L. Liu, and subfamily Pooideae Benth. (Soreng et al. 2017). In account to world grass flora 6 species and some varieties are assigned to Milium (Probatova 1977, 1978, Probatova et al. 2000, Maroofi 2011, WCVP 2021) and a recent revisionary account to 'Grasses of Russia' includes 10 species from 2 sections - Milium (perennials) and Miliellum Tzvelev (annuals) (Tzvelev \& Probatova 2019). To grass flora of India, Milium is solely represented by plants of $M$. effusum L. inhabited to Arunachal Pradesh, Himachal Pradesh, Kashmir, Sikkim,
West Bengal and Uttarakhand states falling to Indian Himalayan Region (Sinha et al. 2019). M. effusum has almost worldwide distribution as to many Temperate, Boreal, Subarctic and Sub-alpine parts of the Northern Hemisphere: from Eastern North America and North Africa across most of Europe to the Urals and the Black Sea, extending eastwards to the Himalaya, China, Korea and Japan, as well as to almost all the Russian Far East, including Kamchatka Peninsula, with exceptions of Magadan Region, Chukotka and North Kurils (Tutin et al. 1950, Cope 1982, Probatova 1985, 2003, Karthikeyan et al. 1989, Probatova et al. 2000, Crins 2007, Kandwal \& Gupta 2009, De Frenne et al. 2017, Probatova \& Seledets 2018, Sinha et al. 2019, Manikandan et al. 2020). Commonly, the species is known as Wood Millet and diffuse Millet, due to its prevalence along with the woodland plant communities, and its cultivar popularly is 
known as 'Aureum' which is a well-established ornamental grass (Crins 2007, De Frenne et al. 2017). M. effusum plants sometimes are aromatic (coumarin like scent), and it is one of scented grass used in the traditional customs in Norway and locally known as 'Haisennagress' (Alm 2015). However, the fragrant plants of $M$. effusum are rare in Russia and adjacent countries (found once in Ukraine by Probatova). Karyologically, Milium is unique to grass family having small to medium sized chromosomes and is a polyploid genus sporting chromosome numbers of $2 \mathrm{n}=8,10,14,18,22$, 28 and 42 stemmed on basic numbers of $\mathrm{x}=4,5,7,9$ and 11 (Sokolovskaya \& Probatova 1976, Probatova 2021) and dysploid events are key impetus to karyological evolution. As polyploid and dysploid events are conventional phenomena to grasses also to Milium, the cytological status of such taxa of wider distribution remains unconfirmed until extensive to intensive exploration studies to un-accessed regions of biodiversity hotspots. As concerned, the present study is in a line of endeavour to explore phytogeographically distinct and unexplored regions of Himalaya, India (Kumar et al. 2014, Singhal et al. 2014). This study was aimed to enlist the existing chromosome number diversity in the low to high altitudinal grass species growing in the Uttarkashi district in relation to global distribution status. During the survey we encountered with $M$. effusum which is generally scanty in distribution to global floristic regions and the same is in the forest regions of Uttarkashi where it is restricted over high altitude regions (above $3000 \mathrm{~m}$ ). So, the present cytological report includes observations of undertaken study to support the cytogeographic account, analysis of meiotic behaviour, pollen fertility study, and to present a short note to polymorphic and polyploid nature of $M$. effusum.

\section{MATERIAL AND METHODS}

The plants of $M$. effusum were collected from the moist vegetation area around Dodital $(3200 \mathrm{~m})$ and on the way to Darwa (3400 m) Mts. above Assi Ganga Valley (3054'09"N 78³1'09"E),

Figure 1 Maps showing geographical location of Indian Himalayan region (IHR), and depicting distribution of plants Milium effusum L. to IHR states
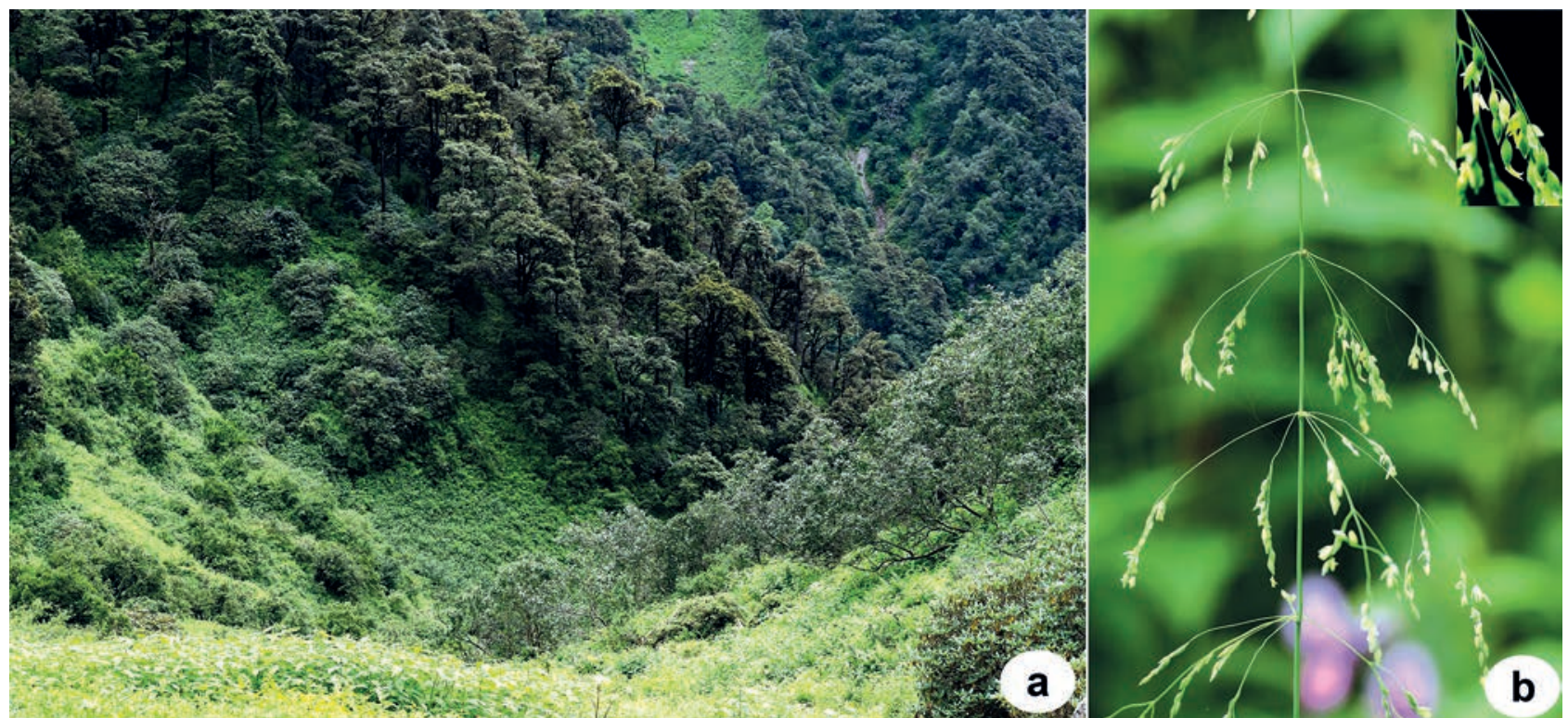

Figure 2 A field photograph showing natural habit of species, mountainous region on way to Darwa (a), and a part of open and spreading panicle, with solitary branch and spikelet sporting yellowish stamens (b) 
Uttarakhand state falling to Indian Himalayan Region (Figs 1, 2a). For this young, as flag leaf enclosed panicles were fixed in Carnoy's fixative (ethanol: chloroform:acetic acid $=6: 3: 1$ ). After $48 \mathrm{~h}$, the materials were transferred to $70 \%$ ethanol and stored in a refrigerator. Meiotic preparations were made by squashing the developing anthers from the unopened florets in $1 \%$ acetocarmine. Pollen fertility was estimated through a stainability test by squashing the mature anthers in a mixture of glycerol and $1 \%$ acetocarmine (1:1). Well-filled pollen grains with completely stained nuclei and cytoplasm were scored as fertile, while partially stained and shrivelled ones as sterile. Preparations of PMCs with well-spread bivalents/ chromosomes, meiotic irregularities, and pollen grains were selected for photomicrographs using a Leica Qwin microscope equipped with a digital imaging system. Vouchers of analyzed plants were deposited in the Herbarium (PUN), Department of Botany, Punjabi University, Patiala.

\section{RESULTS AND DISCUSSION Polymorphic nature - cryptic species complex}

Milium effusum is a perennial herb of polymorphic nature with weak phytocoenotic activity affirmed by morphological variations suggested by previous extensive floristic accounts along with description of analyzed plants. Plants inhabited to North American floristic regions differ from Eurasian origin, primarily in the leaf colour of living plants (glaucous vs. green), longer spikelets, fewer branches at the nodes of the panicle and longer fruits (Haines 2010). Characteristically, North American plants having 2-3 panicle branches at most nodes, spikelets $2.5-5 \mathrm{~mm}$ long and fruit $2.5-3 \mathrm{~mm}$ are described as $M$. effusum subsp. cisatlanticum (Fern.) A. Haines and Eurasian plants with 4-5-6 panicle branches at most nodes, spikelets about $3 \mathrm{~mm}$ long and fruits $2.0 \mathrm{~mm}$ long belongs to M. effusum subsp. effusum (Fernald 1950, Crins 2007, Haines 2010). Besides, Eurasian plants also exhibit morphovariants, like plants of Baikal Siberia (Russia) origin have spikelets rose-violet, 3-3.4 mm long, arranged in large spreading panicles as $M$. effusum var. coloratum Roshev. (Tzvelev 1976) and plants analyzed from Honsu mountains (Japan) are of pubescent form (leaf blades along margins with accurately ciliated hairs, sheaths of lower stem leaves more or less pubescent) and were described as $M$. effusum $\mathrm{f}$. ciliatum Hiyama (Hiyama 1957) and plants of other Eurasian regions including Himalayas as per se the protologue descriptions are associated with M. effusum L. subsp. effusum (Fig. 2b). M. effusum s.l. is almost Holartic species which is defined by degree of bioclimatic continentalization and distribution of species to different tendency gradient zones and association with transformations of ecological ranges, it confirms the supposed polymorphism of M. effusum s.l. (Probatova \& Seledets 2018). A comparative study of $M$. effusum in Northern and Southern regions of Sweden showed to be highly variable as the levels of genetic diversity and allelic richness were lower in Northern Sweden as compared with Southern Sweden (Tyler 2002). In contrast, different measures of geographic structure all showed higher levels of population differentiation in the northern region of Sweden. On the other hand molecular phylogenetic studies also showed the existence of genetic polymorphism associated with phenotype of species (Kotseruba et al. 2017, 2018). Further genomic sequence analysis of plants collected from different regions of Europe, Caucasus, Siberia, Middle Asia, East Asia, and North America splits plants into two distinct clades with the samples of M. effusum from East Asia (Kamchatka, Kuril Islands, Primorskii Krai, Japan, China) clustering into a separate clade than the rest of $M$. effusum samples aggregates together in a second clade with perennials $M$. transcaucasicum Tzvelev and M. schmidtianum K. Koch (all from the section Milium). Conditionally it forms a representation of two realms, European and East Asian, depicting the possibility of the existence of cryptic species (Kotseruba et al. 2008, 2012, 2013). The plant collections (2014-2017) through the Garhwal Himalayan forest regions (Asi Ganga, Bhagirathi, Chaurangi Khal, Har Ki Dun, Jadh Ganga, Rarhi, Yamuna valleys and their low altitude localities) falling in Uttarkashi district (900-4000 m) were made but the plants were found to growing only in the moist and shady sub-alpine slopes within an altitude range of $3000-3400 \mathrm{~m}$ above the Assi Ganga valley (Fig. 2a). This restricted distribution of species possibly may be due to highly specialized nature and adaptive as grass of woodland community (Probatova et al. 2000, De Frenne et al. 2017).

\section{Chromosome number and cytogeography}

The male meiotic study of plants of $M$. effusum scored from Dodital (PUN62907) and Darwa (PUN62432) on exploration revealed that individuals of species are unequivocally sporting common gametic chromosome count of $\mathrm{n}=14$. Chromosome number of $\mathrm{n}=14$ was confirmed from presence of 14 bivalents in the pollen mother cells at diakinesis (Fig. 3a) and metaphase-I (Fig. 3b). The report of present chromosome count of $2 \mathrm{n}=28$ in plants inhabited to the Far Eastern region of Western Himalaya and is in line with similar count recorded by Mehra and Sunder (1969) in a plant scored from Far Western region (Kashmir) Western Himalaya, India. Chromosomally $M$. effusum have been extensively explored from different regions of the globe and, like present count to Himalayan plants, chromosome number of $2 \mathrm{n}=28$ is a widely sported number throughout its distribution (Probatova et al. 2000). Scrutiny of previous known reports of chromosome number/s $(2 \mathrm{n}=14,28)$ associated to $M$. effusum widens the scope of earlier records to blot cytogeography. The most common number of $2 n=28$ is known to be recorded in the plants originated from Europe (Iceland, England, Norway, Denmark, Finland, Belgium, Netherlands, France, Germany, Switzerland, Sweden, Austria, Greece, Slovakia, Bulgaria, Poland, Moldova, Belarus, Ukraine (Tischler 1934, Rohweder 1937, Löve \& Löve 1944, 1956, 1981, Tutin 1950, Sorsa 1962, 1963, Gadella \& Kliphuis 1963, Frey et al. 1977, Majovsky et al. 1978, Skalinska et al. 1978, Strid \& Franzen 1981, Strid \& Andersson 1985, Vachova 1987, Dmitrieva \& Parfenov 1991, DuckertHenriod 1991, Bennett \& Thomas 1991, Bennett \& Bennett 1992, Kozuharov \& Petrova 1991, Lovkvist \& Hultgard 1999, Probatova \& Seledets 2008, Korobkov et al. 2012), from Caucasus (Armenia: Ghukasyan 2004a, b), many times from Russia (Probatova \& Sokolovskaya 1981, Guzik 1984, Rudyka 1990, Sorokin 1990, 1993, Probatova et al. 2000, 2001, 

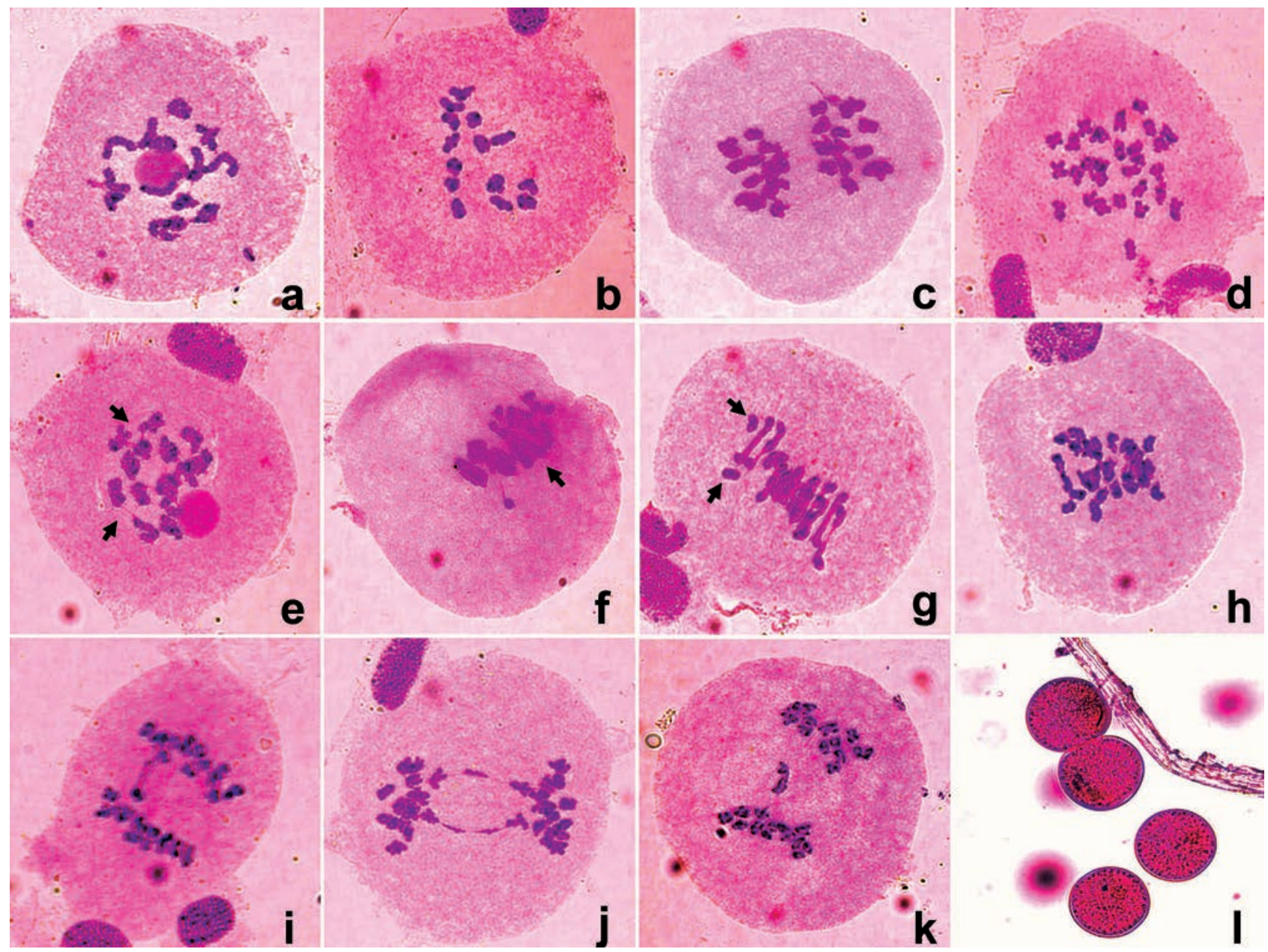

Figure 3 Meiotic course: a - a diakinesis pollen mother cells showing 14 bivalents, $\mathbf{b}$ - a metaphase-I pollen mother cell showing 14 bivalents, c - a pollen mother cell showing 14:14 chromosomes at each A-I pole, $\mathbf{d}-$ an anaphase-I pollen mother cell showing 28 chromosomes, $\mathbf{e}-$ a diakinesis pollen mother cell depicting inter-bivalent connections between 2-5 bivalents in 1-5 groups (arrowed), $\mathbf{f}-$ a pollen mother cell depicting chromatin stickiness (arrowed), $\mathbf{g}-$ a pollen mother cell depicting earlier disjunction of $1-2$ bivalents (arrowed), $\mathbf{h}-\mathbf{a}$ pollen mother cell depicting late disjunction of $1-2$ bivalents, $\mathbf{i}, \mathbf{j}$ - pollen mother cells depicting late disjunction created $1-2$ chromatin bridges, $\mathbf{k}-\mathrm{a}$ pollen mother cell showing lagging bivalent, $\mathbf{1}$ - stained fertile pollen grains

2004, 2008, 2011, 2012, 2015, Seledets \& Probatova 2005, Rodionov et al. 2006, Chepinoga et al. 2012), from Central, South and East Asia (Kazakhstan, India, Japan: Tateoka 1953, Mehra \& Sunder 1969, Probatova \& Seledets 2008), and from North America (Canada: Bowden 1960). Interestingly, in addition to tetraploid count $(2 \mathrm{n}=28)$, the reports of diploid count with chromosome number of $2 n=14$ have also been published from plants explored in Kola Peninsula (North-West Russia: Sokolovskaya \& Strelkova 1960) and from Appenzell and Valais Canton regions of Switzerland (Duckert-Henriod 1991). The wide distribution of tetraploid cytotype seems facilitated by genomic plasticity in relation to structure and function that imparts adaptability through rapid and successful establishment of polyploids in nature (Ma \& Gustafson 2005). The diploid cytotype seems to be a rare (relict?) cytotype which is limited to few individuals further restricted to diminishing habitats. The present cytogeographic streak is an illustrative information on existing chromosomal number diversity in individuals of $M$. effusum.

Besides, tetraploid plants of Sweden origin are also known to possessing a $1 \mathrm{~B}$-chromosome $(2 \mathrm{n}=28+0-1 \mathrm{~B})$ (Lovkvist \& Hultgard 1999) which possibly associated with buffering of genetic diversity and allelic richness in Sweden plants (Tayler 2002). Commonly Bs are known as accessory or supernumerary chromosomes and considered as non-essential components of the genomes found in a wide variety of plants and possess their own meiotic drive and follow non-mendelian inheritance (Jones \& Rees 1982). To origin, Bs arise from the A-chromosomes, but they follow their own pattern of inheritance and accumulation mechanism to future generations. To the constitution of Bs, they are like a "genomic sponge" and accumulate sequences of various origins in a cell (Bednářová et al. 2021).

\section{Meiotic behaviour and polyploid nature}

In relation to meiotic behaviour, during the meiotic course most of the pollen mother cells depicted normal course as seen the regular segregation of 14 bivalents into 14:14 and also as 28 chromosomes at A-I (Fig. 3c, d). However, during the meiotic course, most of the pollen mother cells were observed with normal meiotic configurations, but few meiocytes depicted occurrence of interbivalent connections (Fig. 3e), chromatin stickiness as chromatin masses (Fig. 3f), non-synchronous segregation/disjunction 
of bivalents (Fig. 3g, h), and later phenomenon also noticed in the form of chromatin bridge and laggards at anaphase-I (Fig. 3i-k). Despite meiotic anomalies, the plants were noted with $98-99 \%$ fertile pollen grains of $46.78 \pm 0.86 \mu \mathrm{m}$ size (Fig. 31).

The formation of distal interbivalent connections between $2-5$ bivalents in $1-5$ groups in diakinesis meiocytes seen as loose connections between homoeologs bivalents resulted due to fusion of heterochromatic regions (Thomas \& Revell 1946, Bennett \& Thomas 1991). During later meiotic stages these structures get demolished through directed restriction to paring by diploidizing genes (Jenkins \& Rees 1991). Chromatin stickiness and non-synchronous disjunction in meiocytes depicts some sort of associated genomic changes with spindle apparatus (Kumar \& Singhal 2013, Kumar et al. 2017). Chiasma frequency values in meiocytes of analyzed plants depicted variation over pairing to chromosomes having chiasma per bivalent 1.28-1.31 (Table 1). Close observations to paring as ring or rod bivalent, 68.26-71.06 \% chromosomes were paring as rod bivalent with single terminal chiasma and 28.39-31.23\% chromosomes as ring bivalent with 2-chiasmata and some PMCs also possessed early disjunction created univalents at metaphase-I. Meiotically the tetraploid plants are typical to allopolyploid nature, favours exclusive bivalent formation and higher frequency of rod bivalents (Bennett \& Thomas 1991). This stable diploid like meiotic behaviour in allotetraploid plants is generally due to prior differentiation of homoeologous chromosomes to diploidization pathway which directs pairing of homologous chromosomes as rod-ring bivalents and suppression of pairing of homoeologs (Ladizinsky 1973, Otto \& Whitton 2000, Ramsey \& Schemske 2002, Comai 2005). In polyploid/allopolyploid plants broadly diploidization occurs at cytological and genic levels (see Li et al. 2021) and in case of M. effusum genic diploidization in addition to cytological diploidization seems more implicit force to wide distribution and polymorphic nature. The changes over nuclear content (mean 2C DNA amount: 7.52$10.20 \mathrm{pg}$ ) in tetraploid plants were also reported by Bennett \& Bennett (1992) among wild and botanical garden managed plants and recorded $35.6 \%$ higher content in managed plants than in plants of natural habitat. Further dominance of tetraploid plants of $M$. effusum over diploid cytotype is facilitated by allopolyploid event, which greatly sprouted to biological diversity associated to Milium (Fox et al. 2020) and also to enhanced survival potential of dawning taxa over unfavourable and new habitats (Van de Peer et al. 2021).

\section{CONCLUSION}

The present study upholds the widespread status of tetraploid nature plants of M. effusum, as also Himalayan origin plants are sporting again the chromosome number of $2 \mathrm{n}=28$. Besides, a rare diploid cytotype with chromosome number of $2 \mathrm{n}=14$ suggests intraspecific polyploid nature of $M$. effusum having $2 \mathrm{x}$ and $4 \mathrm{x}$ cytotypes based on $\mathrm{x}=7$. Further, to affirm this nature and conservation of minority cytotype needs exploration and re-reporting of $2 \mathrm{x}$ plants inhabited to Kola Peninsula in Russia and Valais Canton region of Switzerland.

\section{ACKNOWLEDGEMENTS}

Authors wish to thank the University Grants Commission (UGC), New Delhi for financial support under DSA-I, II schemes; Department of Biotechnology (DBT), New Delhi under DBT-IPLS project (BT/PR4548/INF/22/146/2012), and UGC for the award of UGC-BSR-Fellowship to JS (Award letter no. 15610/Research/03/06/2015). Thanks are also due to the Head (Prof. Munruchi Kaur), Department of Botany, Punjabi University, Patiala, for providing necessary laboratory, Herbarium (PUN) and Internet facilities, and Coordinator, University Sophisticated Instrumentation Centre (SIC) for photography. Thanks are also due to Scientist In-charge, Botanical Survey of India, Northern Circle, Dehra Dun for providing the herbarium facility, for identification of voucher specimens.

Ethics declarations. The authors declare that they have no financial and personal relationships with other people or organizations that can inappropriately influence their work. All data and material can be available from the authors.

\section{LITERATURE CITED}

Alm, T. 2015. Scented grasses in Norway-Identity and uses. Journal of Ethnobiology and Ethnomedicine 11:83.

Bednářová, M., M. Karafiátov, E. Hřibová, J. Bartoš 2021. B chromosomes in genus Sorghum (Poaceae). Plants 10:505.

Bennett, S.T. \& S.M. Thomas 1991. Karyological analysis and genome size in Milium (Gramineae) with special refe-

Table: 1. Analysis of meiotic configurations in PMCs (Diakinesis and M-I) depicting chiasma frequency per PMC and per bivalent and percentage of chromosomes associated as ring/rod bivalents.

\begin{tabular}{|c|c|c|c|c|c|c|c|}
\hline \multirow{2}{*}{ Accession } & \multirow{2}{*}{ PMCs type } & \multirow{2}{*}{$\begin{array}{l}\text { No. of PMCs } \\
\text { Analyzed }\end{array}$} & \multicolumn{2}{|c|}{ Bivalents } & \multirow{2}{*}{$\begin{array}{c}\text { Univalents* } \\
\text { I }\end{array}$} & \multirow{2}{*}{$\begin{array}{c}\text { Chiasma per } \\
\text { PMC } \\
\text { (Mean } \pm \text { SD) }\end{array}$} & \multirow{2}{*}{$\begin{array}{c}\text { Chiasma per } \\
\text { bivalent }\end{array}$} \\
\hline & & & Ring II & Rod II & & & \\
\hline PUN62907 & $\begin{array}{l}\text { PMCs with bivalents } \\
\text { and univalents }\end{array}$ & 39 & $\begin{array}{l}155 / 546 \\
(28.39 \%)\end{array}$ & $\begin{array}{l}388 / 546 \\
(71.06 \%)\end{array}$ & $\begin{array}{l}6 / 546 \\
(0.55 \%)\end{array}$ & $\begin{array}{c}16-21 \\
(17.90 \pm 1.93)\end{array}$ & 1.28 \\
\hline \multicolumn{3}{|c|}{$\begin{array}{l}\text { Number and \% of chromosomes involved in } \\
\text { chromosomal associations }\end{array}$} & $\begin{array}{l}310 / 1098 \\
(28.39 \%)\end{array}$ & $\begin{array}{l}776 / 1098 \\
(71.06 \%)\end{array}$ & $\begin{array}{l}6 / 1098 \\
(0.55 \%)\end{array}$ & & \\
\hline PUN62432 & $\begin{array}{l}\text { PMCs with bivalents } \\
\text { and univalents }\end{array}$ & 42 & $\begin{array}{l}183 / 586 \\
(31.23 \%)\end{array}$ & $\begin{array}{l}400 / 586 \\
68.26 \%\end{array}$ & $\begin{array}{l}6 / 586 \\
(0.51 \%)\end{array}$ & $\begin{array}{c}15-23 \\
(18.24 \pm 2.22)\end{array}$ & 1.31 \\
\hline \multicolumn{3}{|c|}{$\begin{array}{l}\text { Number and \% of chromosomes involved in } \\
\text { chromosomal associations }\end{array}$} & $\begin{array}{l}366 / 1172 \\
(31.23 \%)\end{array}$ & $\begin{array}{l}800 / 1172 \\
(68.26 \%)\end{array}$ & $\begin{array}{c}6 / 1172 \\
(0.51 \%)\end{array}$ & & \\
\hline
\end{tabular}

\footnotetext{
* $\mathrm{x}$ univalents $=\mathrm{x} / 2$ bivalents
} 
rence to polyploidy and chromosomal evolution. Genome 34:868-878.

Bennett, S.T. \& M.D. Bennett 1992. Variation in nuclear DNA amount between wild and cultivated populations of Milium effusum $(2 \mathrm{n}=28)$. Genome 35:1050-1053.

Bowden, W.M. 1960. Chromosome numbers and taxonomic notes on Northern grasses III. Twenty-five genera. Canadian Journal of Botany 38:541-557.

Chepinoga, V.V., A.A. Gnutikov, R.S. Moritz, P.I. Lubogoschinsky \& A.S. Sergeyeva 2012. In: K. Marhold \& I. Breitwieser (eds). IAPT/IOPB chromosome data 13. Taxon 61:892-894.

Comai, L. 2005. The advantages and disadvantages of being polyploid. Nature Reviews Genetics 6:836-846.

Cope, T.A. 1982. Poaceae. In: Flora of Pakistan. No. 143 E. Nasir \& S.I. Ali (eds), Department of Botany, University of Karachi, Karachi.

Crins, W.J. 2007. Milium. In: Flora of North America, vol. 24. (M.E. Barkworth, K.M. Capels, S. Long, L.A. Anderton \& M.B. Piep (eds), pp. 778-780. Oxford University Press, New York, NY.

De Frenne, P., J. Brunet, M. Cougnon, G. Decocq, B.J. Graae, J. Hagenblad, M. Hermy, A. Kolb, I.H. Lemke, S. Ma \& A. Orczewska 2017. Biological flora of the British Isles: Milium effusum. Journal of Ecology 105:839-858.

Dmitrieva, C.A. \& V.I. Parfenov. 1991. Caryology of the flora as the basis of cytogenetic monitoring (the Bereainsky Biosphere Reserve). Nauka i tekhnika, Minsk, 231 pp. (in Russian). [Амитриева С.А, Парфенов В.И. 1991. Кариология флоры как основа цитогенетического мониторинга (на примере Березинского биосферного заповедника). Минск: Наука и техника. 231 с.].

Duckert-Henriod, M.M. 1991. In: G. Kamari, F. Felber \& F. Garbari (eds). Mediterranean chromosome number reports 1 (7-25). Flora Mediterranea 1:229-236.

Fernald, M.L. 1950. The North American variety of Milium effusum. Rhodora 52:218-222.

Fox, D.T., D.E. Soltis, P.S. Soltis, T.L. Ashman \& Y. Van de Peer 2020. Polyploidy: A biological force from cells to ecosystems. Trends in Cell Biology 30:688-694.

Frey, L., Z. Mirek \& M. Mizianty 1977. Contribution to the chromosome numbers of Polish vascular plants. Fragmenta Floristica et Geobotanica 23:317-325.

Gadella, T.W. \& E. Kliphuis 1963. Chromosome numbers of flowering plants in the Netherlands. Acta Botanica Neerlandica 12:195-230.

Ghukasyan, A. 2004a. Extent of karyological study of Armenian grasses (Poaceae). Flora i Rastitel'nye Resursy Armenii 15:74-84 (in Russian). [Гукасян А.Г. 2004. Кариологическая изученность зАаков (Роасеае) Армении // Флора и растительные ресурсы Армении. Вып. 15 C. 74-84].

Ghukasyan, A. 2004b. On the karyology of the genus Milium L. (Poaceae). Flora $i$ Rastitel'nye Resursy Armeni 15:89-90 (in Russian). [Гукасян А.Г. К кариологии рода Millium L. (Poaceae) / / ФАора и растительные ресурсы Армении. Вып. 15. С. 89-90].

Guzik, M.B. 1984. Chromosomal numbers of some wild cereals of the Urals. In: Ecology of plantpollination (M.B. Guzik, ed.), pp. 82-86, Perm (in Russian). [Гузик М.Б. 1984. Хромосомные числа некоторых дикорастущих зАаков Предуралья // Экология опыления растений / поА реА. М.Б. Гузик. Пермь. С. 82-87].
Haines, A.A. 2010. New combinations in the New England tracheophyte flora. Stantec Botanical Notes 13:1-8.

Hiyama, K. 1957. A form of Milium effusum L. Journal of Japanese Botany 9:274.

Jenkins, G. \& H. Rees 1991. Strategies of bivalent formation in allopolyploid plants. Proceedings of the Royal Society of London. B: Biological Sciences 243:209-214.

Jones, R.N. \& H. Rees 1982. B Chromosomes. Academic Press, New York.

Kandwal, M.K. \& B.K. Gupta 2009. An update on grass flora of Uttarakhand. Indian Journal of Forestry 32:657-668.

Karthikeyan, S., S.K. Jain, M.P. Nayar \& M. Sanjappa 1989. Florae Indicae Enumeratio Monocotyledonae. Botanical Survey of India, Calcutta.

Korobkov, A.A., V.V. Kotseruba, N.S. Probatova \& A.A. Gnutikov 2012. In: K. Marhold \& I. Breitwieser (eds) IAPT/IOPB chromosome data 13. Taxon 61:895-896.

Kotseruba, V.V., N.S. Probatova \& F.R. Blattner 2008. Polymorphism of Milium effusum (Poaceae) in geographic range of the species, according to ITS ribosomal DNA sequencing. In: Fundamental and Applied Problems of Botany at the beginning of the 21 century, part 3: Molecular taxonomy and biosystematics. (L.V. Bagmet et al., eds), pp. 39-42, Karelian Scientific Center RAS, Petrozavodsk (in Russian). [Коцеруба В.В., Пробатова Н.С., Блаттнер Ф. 2008. Полиморфизм Milium effusum (Poaceae) в географическом ареале вила, по Аанным ITS секвенирования рибосомальной $\Delta$ НК // Фундаментальные и приклаАные проблемы ботаники в начале 21 века: материалы Всероссийской конференции / под реА. А.В. Багмет и Ар. Петрозаводск: Карельский научный центр РАН. Ч. 3. C. 39-42].

Kotseruba, V.V., V.S. Shneyer, N.S. Probatova, A. Houben \& F.R. Blattner 2012. Milium effusum (Poaceae) in East Asia differs strongly in ITS sequence from conspecific plants in other parts of the species range. In: The East Asian Flora and its role in the formation of the world's vegetation. Abstr. of the Symposium (Sept. 23-27, 2012, Vladivostok, Russia) (P.V. Krestov, ed.), p. 34, Vladivostok.

Kotseruba, V.V., V.S. Shneyer, N.S. Probatova, A. Houben, K. Pistrick \& F.R. Blattner 2013. Are there any cryptic species inside grass Milium effusum L. with a high molecular polymorphism? In: BioSyst.EU 2013 Global systematics! 18-22 February 2013 (A. Kroh, B. Berning, E. Haring, M. Harzhauser, H. Sattmann, J. Walochnik, D. Zimmermann \& M. Zuschin, eds), p. 114, Nobis Austria, Wienna.

Kotseruba, V.V., E.M. Machs, N.S. Probatova, A. Huben \& F.R. Blattner 2017. Molecular polymorphism of Milium effusum L. (Poaceae). In: Systematics and Evolutionary morphology of plants: Materials of the conf. dedicated to 85-anniversary of N Tikhomirov (Moscow, 31 Jan.-3 Febr. 2017) (D.D. Sokoloff et al., eds), pp. 213-217, Max Press, Moscow (in Russian). [Коцеруба В.В., Мачс Э.М., Пробатова Н.С., Хубен А., Блаттнер Ф. 2017. Молекулярный полиморфизм вида Milium effusum L. (Роасеае) // Систематика и эволюционная морфология растений: материалы конференции, посвященной 85-летию со Аня рожАения В.Н. Тихомирова / ред. колм. А.А. Соколов и ар. М.: МАКС Пресс. С. 213-217].

Kotseruba, V.V., E. Machs, O. Sizonenko \& N.S. Probatova 2018. Molecular polymorphism of the species Milium effusum L. (Poaceae) In: International Agriculture, Environment and Health Congress, Aydin, 26-28 October 2018 (C. Turgut, P.B. Kurt Karakus \& S. Öğüt, eds), p. 2180, Aydin.

Kozuharov, S.I. \& A.V. Petrova 1991. Chromosome numbers of Bulgarian angiosperms. Fitologija 39:72-77. 
Kumar, P. \& V.K. Singhal 2013. Chromosome number and secondary chromosomal associations in wild populations of Geranium pratense L. from the cold deserts of LahaulSpiti (India). Cytology and Genetics 47:107-114.

Kumar, P., P.K. Rana, V.K. Singhal \& R.C. Gupta 2014. Cytogeography and phenomenon of cytomixis in Silene vulgaris from cold regions of Northwest Himalayas (India). Plant Systematics and Evolution 300:831-842.

Kumar, P., V.K. Singhal \& S.K. Srivastava 2017. Secondary associations in 'Himalayan pink' (Dianthus angulatus Royle ex Benth., Caryophyllaceae) from cold deserts of LahaulSpiti. Genetika 49:87-94.

Ladizinsky, G. 1973. Genetic control of bivalent pairing in the Avena strigosa polyploid complex. Chromosoma 42:105-110.

Li, Z., M.T. McKibben, G.S. Finch, P.D. Blischak, B.L. Sutherland \& M.S. Barker 2021. Patterns and processes of diploidization in land plants. Annual Review of Plant Biology 72:387-410.

Löve, A. \& D. Löve 1944. Cytotaxonomical studies on boreal plants. III. Some new chromosome numbers of Scandinavian Plants. Arkiv för Botanik 31:1-22.

Löve, A. \& D. Löve 1956. Cytotaxonomical conspectus of Icelandic flora. Acta Horti Gothoburgensis 20:65-291.

Löve, A. \& D. Löve 1981. In: A. Löve (ed.). Chromosome number reports LXXI. Taxon 30:509-511.

Lovkvist, B. \& U.M. Hultgard 1999. Chromosome numbers in South Swedish vascular plants. Opera Botanica 137:1-42.

Ma, X.F. \& J.P. Gustafson 2005. Genome evolution of allopolyploids: A process of cytological and genetic diploidization. Cytogenetic and Genome Research 109:236-249.

Majovsky, J. 1978. Index of chromosome numbers of Slovakian flora (Part 6). Acta Facultatis Rerum Naturalium Universitatis Comenianae, Botanica 26:1-42.

Manikandan, R., C. Murugan, N.S. Ponnurangam \& M.D. Ramasamy 2020. Flowering plants of Govind Pashu Vihar Wildlife Sanctuary, Western Himalava: with emphasis on high altitude threatened medicinal plants. In: Phytomedicine: Research and Development (P. Thangaraj, ed.), pp. 93-130, CRC Press, Boca Raton.

Mehra, P.N. \& S. Sunder 1969. Cytological investigations in the North Indian grasses (Part II). Research Bulletin of the Panjab University. Science. 20:503-539.

Maroofi, H. 2011. A new species and a new record of Poaceae family from Iran. Iranian Journal of Botany 17:1014.

Otto, S.P. \& J. Whitton 2000. Polyploid incidence and evolution. Annual Review of Genetics 34:401-437.

Probatova, N.S. 1977. Contribution to taxonomy of the genus Milium L. (Poaceae). Novitates Systematicae Plantarum Vascularium 14:6-14 (in Russian). [Пробатова Н.C. 1977. К систематике рода Milium L. (Роасеае) // Новости систематики высших растений. Т. 14. С. 6-14.]

Probatova, N.S. 1978. Infraspecific taxonomy of Milium vernale Bieb. In: VI Delegate Forum of the All-Union Botanical Society (Kishinyou, 12-17 Sept. 1978), pp. 309-310, Leningrad (in Russian). [Пробатова Н.С. 1978. Внутривидовая систематика Milium vernale Bieb.VI Аелегатский съезА Всесоюзного ботанического общества (Кишинев, 12-17 сент. 1978 г.): тезисы докладов. Аенинград. С. 309-310].

Probatova, N.S. 1985. Bluegrasses, or cereals - Poaceae Barnh. (Gramineae Juss.) In: Vascular plants of the Soviet Far East, vol. 1 (S.S. Kharkevich, ed.), pp. 89-382, Nauka, Leningrad (in Russian). [Пробатова Н.С. 1985. Мятликовые, или злаки - Poaceae Barnh. (Gramineae Juss.) / / Co- судистые растения советского Аальнего Востока / отв. ред. С.С. Харкевич. Аенинград: Наука. Т. 1. С. 89-382].

Probatova, N.S. 2003. Family Poaceae. In: Vascular Plants of the Russian Far East. Vol. 1. Lycopodiophyta, Juncaceae, Poaceae (Gramineae). S.S. Kharkevich \& N.N. Tzvelev, eds), p. 87-488, Science Publishers Inc., Enfield, New Hampshire, USA.

Probatova, N.S. 2021. Contribution to chromosome studies on Milium vernale aggr. (Poaceae). In: N.S. Probatova (ed.) Botanica Pacifica plant chromosome data 1. Botanica Pacifica 10:117.

Probatova, N.S. \& V.P. Seledets 2008. In: K. Marhold \& G.N. Feliner (eds). IAPT/IOPB chromosome data 5. Taxon 57:555-558.

Probatova, N.S. \& V.P. Seledets 2018. Milium effusum (Poaceae): Transformation of the ecological range of the species in different regions of Eurasia. Uchenye Zapiski Zabaikalskogo gosudarstvennogo universiteta. Seriya Biologicheskie nauki13(1):16-24 (in Russian). [Пробатова Н.С., Селедец В.П. 2018 Milium effusum (Роасеае): трансформация экологического ареала вида в разАичных регионах Евразии Ученые записки Забайкальского государственного университета. Серия: Биологические науки. Т. 13, № 1. С. 16-24].

Probatova, N.S. \& A.P. Sokolovskaya 1981. Karyological study of vascular plants of the Islands of the Far Eastern State Marine Reserve. In: Flowering plants of the Far Eastern Marine Reserve, pp. 92-114, Vladivostok (in Russian). [Пробатова Н.С., Соколовская А.П. 1981. Кариологическое исследование сосудистых растений островов Аальневосточного государственного морского заповедника // Цветковые растения островов АаАьневосточного морского заповедника. ВАадивосток С. 92-114].

Probatova, N.S., E.G. Rudyka \& S.L. Gromik 2000. Caryotaxonomy of the genus Milium L. and some related genera of grasses (Poaceae). Komarov Memorial Lectures 46: 105-146 (in Russian). [Пробатова Н.С., Рудыка Э.Г., Громик С.А. 2000. Кариосистематика рода Milium L. и близких родов змаков (Роасеае) // Комаровские чтения. Вып. 46. С. 105-146].

Probatova, N.S., E.G. Rudyka \& S.A. Shatalova 2001. Chromosome numbers in some plant species from the suburbs of Vladivostok city (Primorsky Region). Botanicheskii Zhurnal 86:168-172 (in Russian). Пробатова Н.С., Рудыка Э.Г., Шаталова С.А. 2001. Числа хромосом некоторых видов фморы окрестностей г. ВАадивостока (Приморский край) // Ботанический журнац. Т. 86, № 1. С. 168-172].

Probatova, N.S., E.G. Rudyka, A.E. Kozhevnikov \& Z.V. Kozhevnikova 2004. Chromosome numbers of some representatives of the flora of the Primorsky Territory. Botanicheskii Zhurnal 89(7):1209-1217 (in Russian). [Пробатова Н.С., Рудыка Э.Г., Кожевников А.Е., Кожевникова 3.В. 2004. Числа хромосом представителей флоры Приморского края. // Ботанический журнал. Т. 89, № 7. С. 1209-1217].

Probatova, N.S., E.G. Rudyka, V.P. Seledets \& V.A. Nechaev 2008. In: K. Marhold \& G.N. Feliner (eds). IAPT/IOPB chromosome data 6. Taxon 57:1268-1271.

Probatova, N.S., S.G. Kazanovsky, E.G. Rudyka, V.Y. Barkalov, V.P. Seledets \& V.A. Nechaev 2011. In: K. Marhold \& G.N. Feliner (eds). IAPT/IOPB chromosome data 12. Taxon 60:1790-1794.

Probatova, N.S., S.G. Kazanovsky, E.G. Rudyka, V.P. Seledets \& V.A. Nechaev 2012. In: K. Marhold \& G.N. Feliner (eds). IAPT/IOPB chromosome data 13. Taxon 61:899-902.

Probatova, N.S., V.P. Seledets \& V.Y. Barkalov 2015. Chromosome numbers in some species of Poaceae from Russia. Botanica Pacifica 4:59-67. 
Ramsey, J. \& D.W. Schemske 2002. Neopolyploidy in flowering plants. Annual Review of Ecology, Evolution, and Systematics 33:589-639.

Rohweder, H. 1937. Versuch zur erfassung der mengenmäBigen bedeckung des darss und zingst mit polyploiden pflanzen. Ein beitrag bedeutung der polyploidie bei der eroberung neuer lebensräume. Planta. Archiv für Wissenschaftliche Botanik 27:501-549.

Rodionov, A.V., E.O. Punina, M.A. Dobroradova, N.B. Tyupa \& N.N. Nosov 2006. Chromosome numbers of some grasses (Poaceae): Aveneae, Poeae, Phalarideae, Phleeae, Bromeae, Triticeae. Botanicheskii Zhurnal 91:615-627 (in Russian). (Родионов А.В., Пунина Е.О., Аоброрадова М.А., Тюпа Н.Б., Носов Н.Н. 2006. Хромосомные числа некоторых зцаков (Роасеаe): Aveneae, Poeae, Phalarideae, Phleeae, Bromeae, Triticeae // Ботанический журнал. T. 91, № 4. C. 615-627.

Rudyka, E.G. 1990. Chromosome numbers of vascular plants from the various regions of the USSR. Botanicheskit Zhurnal 75:1783-1786 (in Russian). [Рудыка Э.Г. 1990. Числа хромосом сосудистых растений из различных регионов СССР // Ботанический журнал. Т. 75, № 12. C. 1783-1786].

Seledets, V.P. \& N.S. Probatova 2005. Ecological range of plant species: karyological aspects. In: Karyology, Karyosystematics and Molecular Phylogeny, pp. 95-97, St. Petersburg, Russia (in Russian). [Селелец В.П., Пробатова Н.С. 2005. Экологический ареал вида у растений: кариологический аспект. // Кариология, кариосистематика и молекулярная филогения растений: тезисы докладов V МежАународного совещания и Школы молодых ученых по кариологии, кариосистематике и молекулярной систематике растений. Санкт-Петербург. С. 95-97].

Singhal, V.K., V. Kumari \& P. Kumar 2014. Cytomorphological diversity in some selected members of Poaceae from Parvati Valley in Kullu district of Himachal Pradesh, India. Plant Systematics and Evolution 300:1385-1408.

Sinha, B.K., S.S. Dash \& P. Singh 2019. Plants of Indian Himalayan region (An annotated checklist \&o pictorial guide: PartII). Botanical Survey of India, Kolkata.

Skalinska, M., E. Pogan \& R. Czapik 1978. Further studies in chromosome numbers of Polish Angiosperms. XII. Acta biologica Cracoviensia. Series botanica 21:31-63.

Sokolovskaya, A.P. \& N.S. Probatova 1976. Contribution to karyological characteristics of the genera Milium L. and Holcus L. (Poaceae) Botanicheskii Zhurnal 61(7):969-973 (in Russian). [Соколовская А.П., Пробатова Н.С. 1976. К кариологической характеристике родов Milium L. и Holcus L. (Роaceae). // Ботанический журнал. T. 61, № 7. C. 969-973].

Sokolovskaya, A.P. \& O.S. Strelkova 1960. Geographical distribution of polyploid plant species in Eurasiatic Arctic. Botanicheskii Zhurnal 45:370-381 (in Russian). [Сокомовская А.П., Стрелкова О.С. 1960. Географическое распространение полиплоидных видов растений в Евразиатской Арктике // Ботанический журнал. T. 45, № 3. C. 370-381].

Soreng, R.J., P.M. Peterson, K. Romaschenko, G. Davidse, J.K. Teisher, L.G. Clark, P. Barbera, L.J. Gillespie \& F.O. Zuloaga 2017. A worldwide phylogenetic classification of the Poaceae (Gramineae) II: An update and a comparison of two 2015 classifications. Journal of Systematics and Evolution 55:259-290.
Sorokin, S.N. 1990. Chromosome numbers in members of the Poaceae family from the north-west of the European part of the USSR. Botanicheskii Zhurnal 75(8):1185 (in Russian). [Сорокин С.Н. 1990. Числа хромосом представитемей семейства Роасеае северо-запада европейской части СССР // Ботанический журнал. Т. 75, № 8. С. 1185].

Sorokin, S.N. 1993. Karyosystematic study of some members of the tribe Aveneae (Poaceae). Botanicheskii Zhurnal 78:36-47 (in Russian). [Сорокин С.Н. 1993. Кариосистематическое изучение некоторых представителей трибы Aveneae семейства Роасеае // Ботанический журнал Т. 78, № 4. C. 36-47].

Sorsa, V. 1962. Chromosome numbers of Finnish cormophytes. I. Annales Academiae Scientiarum Fennicae IV. Biologica 58:1-14.

Sorsa, V. 1963. Chromosome numbers of Finnish cormophytes. II. Annales Academiae Scientiarum Fennicae IV. Biologica 68:1-14.

Strid, A. \& I. Anderson 1985. Chromosome numbers of Greek mountain plants. An annotated list of 115 species. Botanische Jahrbücher fur Systematik 107:203-228.

Strid, A. \& R. Franzen 1981. In: A. Löve (ed.). Chromosome numbers reports LXXIII. Taxon 30:829-842.

Tateoka, T. 1953. Karyotaxonomic studies in Poaceae. I. Annual Report of the National of the National Institute of Genetics (Japan) 4:45-47.

Thomas, P.T. \& S.H. Revell 1946. Secondary association and heterochromatic attraction: I. Cicer arietinum. Annals of Botany 10:159-164.

Tischler, G. 1934. Die Bedeutung der Polyploidie für die Verbreitung der Angiospermen, erläutert an den Arten Schleswig-Holsteins, mit Ausblicken auf andere Florengebiete. Botanische Jahrbücher fur Systematik, Pflanzengeschichte und Pflanzengeographie 67:1-36.

Tutin, T.G. 1950. Milium scabrum Merlet. Watsonia 1:345-348.

Tyler, T. 2002. Geographic structure of genetic variation in the widespread woodland grass Milium effusum L. A comparison between two regions with contrasting history and geomorphology. Genome 45:1248-1256.

Tzvelev, N.N. 1976. Grasses of the USSR. Nauka, Leningrad. 788 pp. (in Russian). [Цвелев Н.Н. ЗАаки СССР. Аенинград: Наука. 788 с.].

Tzvelev, N.N. \& N.S. Probatova 2019. Grasses of Russia. KMK Scientific Press, Moscow, 646 pp. (in Russian). [велёв Н.Н., Пробатова Н.С. 2019. ЗАаки России. М: КМК. 646 c.].

Vachova, M. 1987. Karyological study of the Slovak flora XXI. Acta Facultatis Rerum Naturalium Universitatis Comenianae, Botanica 34:27-32.

Van de Peer, Y., T.L. Ashman, P.S. Soltis \& D.E. Soltis 2021. Polyploidy: An evolutionary and ecological force in stressful times. The Plant Cell 33:11-26.

WCVP 2021. World Checklist of Vascular Plants, version 2.0. Facilitated by the Royal Botanic Gardens, Kew. Published on the Internet; http://wcvp.science.kew.org/ Retrieved 06 June 2021. 